Michat Bożęcki*

https://doi.org/10.18778/8220-375-2.09

\title{
Chińska pomoc zagraniczna dla Korei Północnej w XX i XXI wieku
}

\begin{abstract}
Chinese foreign assistance to North Korea in the 20th and 21st century

China's relationship with North Korea has been very close for years, more so than any other state's. However, in the context of Kim Jong-un's controversial political decisions it may prove difficult for an European observer to understand. Imposing sanctions, but at the same time funding an extensive cooperation program with North Korea - the dualism of China's operations in this area makes one wonder about their real motive. Does this relationship still benefit China, or has it become a shameful relic of the past? The aim of this article is to show how this multi-dimensional relationship developed in the 20th century, through the lens of Chinese foreign aid to North Korea. It makes an attempt to answer the question why China is so interested in keeping good relations with its totalitarian neighbour, despite their growing political and ideological differences. Analysis of articles published by scientific journals, news websites, government portals and private company websites has been used to achieve the research goal.
\end{abstract}

Keywords: foreign aid, China-North Korea relations

Słowa kluczowe: pomoc zagraniczna, relacje Chiny-Korea Północna

\section{Wstęp}

Jednym z niewątpliwych filarów współczesnej dyplomacji chińskiej jest program pomocy zagranicznej - People's Republic of China Foreign Aid (中华人民共和国对外援助 ${ }^{1}$ ). Odgrywa on ogromną rolę m.in. w stosunkach Chin z państwami Afryki, Ameryki Południowej oraz Azji Południowo-Wschodniej. W każdym z tych krajów kwitną inwestycje chińskie, wokół których narastają kontrowersje. Zwolennicy widzą w nich szansę na rozwój biedniejszych regionów świata, a przeciwnicy - wyzysk i wykorzystanie taniej

*Absolwent filologii dalekowschodniej Wydziału Filologicznego Uniwersytetu Wrocławskiego, specjalność chińska, student studiów II stopnia, kierunek stosunki międzynarodowe, specjalność orientalna na Wydziale Studiów Międzynarodowych i Politologicznych Uniwersytetu Łódzkiego; e-mail: michal.bozecki8@gmail.com.

1 中华人民共和国商务部对外援助司 (strona internetowa People's Republic of China Foreign Aid), http://yws.mofcom.gov.cn/article/b/ (dostęp: 23.04.2020). 
siły roboczej w formie zbliżonej do kolonializmu (którego ofiarą padły przecież niegdyś same Chiny).

Prawdopodobnie jednak najbardziej kontrowersyjnym regionem objętym programem chińskiej pomocy zagranicznej jest Koreańska Republika Ludowo-Demokratyczna (KRLD). Wspieranie jedynego na świecie państwa totalitarnego o potencjale nuklearnym jest dość oczywistym obiektem krytyki, zarówno mediów, jak i niezależnych obserwatorów na całym świecie. Fakt samej współpracy Chin z rządem Korei Północnej niejednokrotnie widziany jest jako działanie mające na celu podważenie znaczenia sankcji nałożonych na ten kraj z powodu przeprowadzanych co kilka lat kolejnych prób nuklearnych ${ }^{2}$. $\mathrm{Z}$ względu na to, że chińskie dotacje znacznie wykraczają poza niezbędną pomoc humanitarną, często odczytywane są jako próba utrzymania w Korei obecnej, totalitarnej władzy.

Kwestia programu pomocy chińskiej dla Korei Północnej nie jest jednak tak oczywista i jednowymiarowa - przedstawienie jej w ten sposób nie oddaje w pełni wewnętrznych dysonansów i skomplikowania tego zagadnienia. Zadaniem niniejszego artykułu jest przybliżenie czytelnikowi znaczenia chińskiej pomocy zagranicznej dla KRLD, a także próba ukazania jej roli w sposób bardziej szczegółowy, rozpoczynając od zarysu historycznego, a kończąc na czasach współczesnych.

\section{Historia wsparcia Chin dla Korei Północnej w XX wieku}

Formalny początek chińskiego programu pomocy zagranicznej przypada na 23 listopada 1953 roku, niedługo po zakończeniu wojny koreańskiej, wraz z podpisaniem Umowy o współpracy gospodarczej i kulturalnej między Koreańską Republiką Ludowo-Demokratyczną i Chińską Republiką Ludową̧ ${ }^{3}$. W umowie tej Chiny umorzyły swoim sąsiadom dług wojenny w wysokości ponad 360 mln dolarów. Rząd Mao Zedonga wspomógł ich również dotacją na kolejne $400 \mathrm{mln}$ dolarów, oferując jednocześnie pół miliona własnych robotników do naprawy wojennych zniszczeń na obszarze Korei. Oprócz odbudowy dróg, mostów i budynków, program chińskiej pomocy pomógł postawić na nogi koreańskie rolnictwo i służbę medyczną. Działania prowadzone były na niezwykłą skalę, zważając na sytuację materialną ówczesnego rządu Chin - w 1954 roku pochłonęły aż 3,4\% całkowitego budżetu państwa ${ }^{4}$. Wspomagana także przez Związek Radziecki gospodarka Korei Północnej w krótkim czasie powróciła do tempa sprzed wojny, a nawet znacząco je przekroczyła. Lata 50. to również czas szybkiego wzrostu handlu pomiędzy Chinami i KRLD.

${ }^{2}$ J. Reilly, The Curious Case of China's Aid to North Korea, „Asian Survey” 2014, No. 6(54), s. 1158-1183, https://doi.org/10.1525/as.2014.54.6.1158 (dostęp: 13.01.2020).

${ }^{3}$ Mao Zedong's Remarks at the Banquet for the North Korean Government Delegation, Wilson Center Digital Archive 1953, https://digitalarchive.wilsoncenter.org/document/114167 (dostęp: 23.04.2020).

${ }^{4} \mathrm{~J}$. Reilly, op. cit. 
Pomoc Chin dla Korei trudno, oczywiście, uznać za bezinteresowną. Szybkie ustabilizowanie kryzysu na Półwyspie Koreańskim było bardzo ważne dla bezpieczeństwa samych Chin, jak również zachowania równowagi sił w regionie. Korea Północna, w której także po wojnie stacjonowały chińskie wojska, miała przeciwważyć wspieraną przez USA i ONZ Koreę Południową - właśnie stąd interwencja zbrojna wojsk Chińskiej Republiki Ludowej podczas wojny koreańskiej. Mao wiedział, że utrata kontroli nad granicą z Koreą byłby niezwykle niebezpieczna, dlatego zdecydował się interweniować - mimo że prawdopodobnie odbyło się to kosztem liberacji Tajwanu ${ }^{5}$. W języku chińskim relację tę dobrze oddaje analogia 唇齿相依 - „zębów” i „ust”. Bez „ust”, czyli Półwyspu Koreańskiego, odsłonięte są „zęby” - Chiny. Sam Mao Zedong w okresie tuż po wojnie koreańskiej opisywał to w podobny sposób, podkreślając wagę „,heroicznych czynów" Koreańczyków z Północy jako swoistej linii frontu dającej gwarancję bezpieczeństwa Chin. Wszystko to pokazuje, że stosunki ChRL z KRLD nie są przypadkiem typowej relacji wielkiego państwa z małym. Ogromne znaczenie strategiczne Korei w geopolityce Chin sprawia, że mimo relatywnie małej powierzchni i liczby ludności jest to kraj dla nich niezwykle ważny. Chiny potrzebują Korei Północnej niemal tak samo, jak ona potrzebuje ich, co sprawia, że pomoc zagraniczna staje się niezwykle ważnym narzędziem politycznym.

Czas rewolucji kulturalnej w Chinach odcisnął swoje piętno na wszystkich relacjach z zagranicą; wewnętrzne problemy i Wielki Głód osłabiły w tym czasie handel i pomoc chińską zagraniczną, nie wyłączając KRLD. Po tym trudnym okresie, w latach 70., stosunki handlowe między państwami wrócily do normy ${ }^{7}$.

Pomoc Chin dla Korei Północnej w tym czasie opierała się na trzech filarach: handlu barterowym, pożyczkach i szkoleniach. Ponieważ oba kraje w czasach zimnej wojny prowadziły gospodarkę planowaną, ich umowy handlowe były w rzeczywistości zaplanowanymi rządowo wymianami towarów, trwającymi przez czas określony w umowie. Wymiany te najczęściej były bardzo korzystne dla strony koreańskiej, często tak naprawdę był to transfer dóbr z Chin do Korei ${ }^{8}$. Podobnie działały pożyczki oferowane rządowi KRLD przez sąsiada - zasady, na jakich działały, dawały duże pole do manewru podczas spłacania, ich stopy procentowe były niskie (a nawet zerowe), a w przypadkach niespłacenia należności w danym terminie przedłużano czas na spłatę. Niejednokrotnie

${ }^{5}$ J.H. Chung, M. Choi, Uncertain allies or uncomfortable neighbors? Making sense of China-North Korea Relations, 1949-2010, „The Pacific Review” 2013, No. 26/3, https://www.tandfonline. com/doi/abs/10.1080/09512748.2012.759262 (dostęp: 23.04.2020).

6 唇齿相依（汉语成语）_百度百科 (Być blisko jak zęby i usta; analogia chińska), https://baike.baidu.com/item/\%E5\%94\%87\%E9\%BD\%BF\%E7\%9B\%B8\%E4\%BE\%9D/2069313 (dostęp: 23.04.2020).

${ }^{7} \mathrm{~J}$. Choo, Mirroring North Korea's Growing Economic Dependence on China: Political Ramifications, „Asian Survey” 2008, No. 2(48), s. 343-372, https://doi.org/10.1525/as.2008.48.2.343 (dostęp: 23.04.2020).

${ }^{8} \mathrm{~J}$. Reilly, op. cit. 
pożyczki były nawet „odpuszczane”. Pomoc chińska już w tamtym czasie nie była jednak wyłącznie pomocą materialną - organizowano również szkolenia dla koreańskich studentów i specjalistów, prowadzone przez techników przysyłanych przez Pekin?.

Zmiana nastawienia polityki dyplomatycznej Chin na mniej rewolucyjną po reformach końca lat 70. i początku 80. oziębiła stosunki tego kraju z KRLD. Rząd Kim Il-sunga nadal podkreślał wielkie znaczenie Chin w procesie unifikacji Korei pod komunistyczną flagą, Chińska Republika Ludowa zaczęła jednak przywiązywać większą wagę do utrzymania pokoju i stabilizacji w regionie. Dowodem na to mogą być słowa ówczesnego chińskiego ministra spraw zagranicznych, Huang Hua, ze stycznia 1980 roku: „Mało prawdopodobne jest, że w najbliższej przyszłości nastąpi unifikacja Korei (...) Stabilność w rejonie Półwyspu Koreańskiego przyczynia się do stabilności całego regionu [Azji Wschodniej - M.B.]"10. Rozbieżności w sposobie myślenia i celach obu państw sprawiły, że Koreańczycy skupili się bardziej na relacjach ze Związkiem Radzieckim. Rozwój handlu między Chinami i Koreą Północną ustał, szczególnie po roku 1981 - między krajami wciąż jednak przepływały towary o wartości między 400 a $500 \mathrm{mln}$ dolarów rocznie ${ }^{11}$. Razem $\mathrm{z}$ handlem zwolniła także pomoc zagraniczna Chińczyków dla Korei, która jednak wciąż odpowiadała za niemal 30\% całej pomocy zagranicznej ofiarowanej KRLD w latach 80 . W tej kwestii Chiny wyprzedzał nieznacznie jedynie Związek Radziecki ${ }^{12}$.

Wraz z adaptacją polityki „dobrego sąsiada” (睦邻友好) po roku 1989 Chiny rozpoczęły proces normalizacji stosunków z państwami ościennymi, w tym z Koreą Południową. Mimo niezadowolenia KRLD, w 1992 roku nastąpiła pełna normalizacja stosunków chińsko-południowokoreańskich ${ }^{13}$. Postępująca pragmatyzacja polityki chińskich stosunków ekonomicznych z zagranicą doprowadziła do zmian także w relacjach z Koreą Północną. W 1992 roku Chiny zmienily sposób handlu z sąsiadem - z planowego na rynkowy. Frustracja ChRL, związana z brakiem poszanowania przez stronę koreańską terminów spłat długów, przyczyniła się do końca ,,przyjacielskich” cen w handlu z KRLD ${ }^{14}$ oraz spadku znaczenia programu pomocy zagranicznej w tym obszarze. Nagły wzrost cen importu z Chin (w tym artykułów żywnościowych) i upadek ZSRR, dotychczasowego głównego partnera handlowego Korei Północnej, połączone z niespodziewaną katastrofą naturalną, miały tragiczne skutki. Fala powodzi i susz $\mathrm{w}$ odizolowanej politycznie i handlowo KRLD dopełniła dzieła znisz-

\footnotetext{
${ }^{9}$ Ibidem.

${ }^{10}$ J.H. Chung, M. Choi, op. cit.

${ }^{11} \mathrm{~J}$. Choo, op. cit.

${ }^{12} \mathrm{~J}$. Reilly, op. cit.

${ }^{13}$ Ibidem.

${ }^{14} \mathrm{~J}$. Choo, op. cit.
} 
czenia; w 1995 roku w kraju nastała klęska głodu ${ }^{15}$. W czasie kryzysu Chiny stały się największym źródłem pomocy humanitarnej dla Koreańczyków. Oprócz bezpośrednich gestów, jak wysyłka żywności, przyjęły około 300 tysięcy północnokoreańskich imigrantów ${ }^{16}$.

Sytuacja ta niewątpliwie miała wpływ na ponowne zacieśnienie stosunków między państwami w kolejnych latach. Od 1995 roku powróciły „przyjacielskie” ceny na importowane z ChRL artykuły i surowce. Podpisany został również nowy, pięcioletni plan pomocy zagranicznej dla Korei Północnej. Już w roku 1997 odnotowano wzrost handlu między państwami. Od 2000 roku przybrał on niespotykane wcześniej tempo, wzrastając o $30 \%$ rocznie aż do roku $2004^{17}$.

\section{Obecna pomoc chińska dla KRLD}

W obecnych czasach działalność Chin w programie pomocy zagranicznej dla Korei Północnej przybiera różnorodne formy. Oprócz zapewniania dostaw żywności, wsparcia w sytuacjach kryzysowych i korzystnego handlu dobrami niespotykanymi w samej Korei, ogromne znaczenie dla gospodarki kraju mają kolejne chińskie inwestycje ${ }^{18}$.

Większość decyzji dotyczących chińskiego programu pomocy zagranicznej podejmowana jest podczas wizyt dyplomatycznych. Kluczową rolę w tym procesie odgrywają dyplomaci - ich zadaniem jest ewaluacja proponowanych przez przedstawicieli KRLD projektów; decyzja o zgodzie na dany układ ma kluczowy wpływ na relacje między państwami. W przypadku takich okazji, jak święta narodowe czy wybranie nowego lidera, projekty są stosunkowo większe. Dla przykładu, podpisanie takiej „umowy-prezentu” miało miejsce podczas przejęcia władzy przez Kim Jong-una ${ }^{19}$, jak również w setną rocznicę narodzin Kim Il-sunga ${ }^{20}$. W obu przypadkach Chiny przekazały Korei Północnej m.in. materiały konstrukcyjne i żywność o łącznej wartości kilkudziesięciu milionów dolarów.

Obiektem inwestycji chińskich w Korei Północnej są m.in. fabryki, mosty, elektrownie, drogi i połączenia kolejowe. Liczne większe projekty mają znaczenie symboliczne, jak renowacja Mostu Przyjaźni Chińsko-Koreańskiej ${ }^{21}$ lub

\footnotetext{
${ }^{15}$ Ibidem.

${ }^{16} \mathrm{~J}$. Reilly, op. cit.

${ }^{17} \mathrm{~J}$. Choo, op. cit.

${ }^{18} \mathrm{~J}$. Lin, M. Jin, 金正恩执政后朝鲜经济好转原因及其走势 (Przyczyny i trendy poprawy ekonomicznej w Korei Północnej po przejęciu władzy przez Kim Jong Una), 国外马克思主义政 党研究网 (Sieć badawcza zagranicznej partii marksistowskiej) 2020, http://www.ccnumpfc.com/ index.php/View/147.html (dostęp: 23.04.2020).

${ }^{19}$ Ibidem.

${ }^{20} \mathrm{~J}$. Reilly, op. cit.

${ }^{21}$ H. Kwon, The Korean War and Sino-North Korean Friendship 朝鮮戦争と中朝友好関係, „The Asia-Pacific Journal/ Japan Focus” 2013, No. 11/32/4, https://apjjf.org/2013/11/32/HeonikKwon/3982/article.html (dostęp: 20.04.2020).
} 
budowa mostu na rzece Tumen, na granicy Chin i Korei Północnej ${ }^{22}$. Oprócz oczywistych funkcji praktycznych, mają one za zadanie ukazywać potęgę współpracy obu krajów i więzi, które je łączą.

Jednym z centralnych komponentów obecnego programu pomocy zagranicznej Chin są programy szkoleniowe i edukacyjne; nie inaczej jest w przypadku Korei Północnej. Od wczesnych lat 2000. prowadzone są coroczne wymiany studenckie ${ }^{23}$. Chiny są również odpowiedzialne za rozwój nauki języka chińskiego w KRLD: wysyłają nauczycieli i materiały do nauki do koreańskich szkół. Fundowane są też szkolenia dla wysoko postawionych przedstawicieli partii, mające przygotować ich do współpracy w powstających chińsko-koreańskich strefach ekonomicznych ${ }^{24}$.

\section{Handel i pomoc KRLD a sprawa chińska}

Ogromna liczba inwestycji chińskich, jak również decyzje polityczne władz Korei Północnej w ostatnich latach coraz bardziej uzależniają ten kraj od potężniejszego sąsiada. Hojne inwestycje Chin i ich ogromna pomoc dla kraju Kim Jong-una mają niebagatelne znaczenie. Trudno jednak nie zadać sobie pytania, dlaczego Chinom aż tak zależy na KRLD?

Pierwszą problematyczną kwestią jest tutaj sprawa handlu Chin z Koreą Północną. Statystyki z ostatnich lat wykazują, że faworyzowanie Korei w handlu to kwestia przeszłości. O ile program pomocy zagranicznej działa w tym kraju niezwykle prężnie, ceny towarów eksportowanych i sprzedawanych przez chińskie firmy znacznie wzrosły. Wbrew pozorom znaczy to jednak tylko tyle, że stały się one podobne jak w relacjach z innymi państwami. Dodatkowo, chińscy przedsiębiorcy są bardzo zachęcani przez władze do inwestowania we współpracę z firmami koreańskimi. Niesymetryczność relacji handlowych wynika zatem z czegoś zupełnie innego: przedmiotu transakcji. Korea nie jest krajem bogatym w tradycyjnym sensie, posiada jednak niezwykle bogate złoża naturalne. Większość dóbr eksportowanych do Chin to właśnie dobra nieodnawialne, takie jak antracyt czy węgiel. Głównymi towarami importowym z Chin są zaś materiały budowlane, różnorakie urządzenia, tekstylia oraz ziar-

22 中华人民共和国政府和朝鲜民主主义人民共和国政府矢于共同建设、管理和维护中 朝图们一南阳口岸新界河公路桥的协定 (Umowa między rządem Chińskiej Republiki Ludowej i rządem Koreańskiej Republiki Ludowo-Demokratycznej w sprawie wspólnej budowy, zarządzania i utrzymania mostu na rzece Tumen-Nanyang w Nowym Terytorium), 中华人民共和国 外交部 (Ministerstwo Spraw Zagranicznych Chińskiej Republiki Ludowej), 2015, https://www. fmprc.gov.cn/web/ziliao_674904/tytj_674911/tyfg_674913/t1453671.shtml (dostęp: 2.04.2020).

${ }^{23}$ S. Chen, China Prepared to End North Korea Student Exchanges, „South China Morning Post” 2017, https://www.scmp.com/news/china/article/2122309/china-warns-it-ready-end-north-korea-student-exchanges-after-latest (dostęp: 23.04.2020).

${ }^{24} \mathrm{~J}$. Reilly, op. cit. 
no. Układ ten grozi więc wyeksploatowaniem koreańskich złóż naturalnych, co niesie za sobą zagrożenie dla tego kraju ${ }^{25}$.

Drugą, jeszcze bardziej intrygującą kwestią jest uczestnictwo rządu chińskiego w międzynarodowych sankcjach nałożonych na Koreę Północną, spowodowanych prowadzonym przez rząd Kim Jong-una programem nuklearnym. Z każdym kolejnym związanym z nim działaniem Chiny nakładały na Koreę kolejne sankcje. W odpowiedzi na próbę ponownego uruchomienia w 2003 roku przez KRLD obiektów przeznaczonych do badań nuklearnych, Chiny na trzy dni odcięly dostawy benzyny do Pyongyangu. Po testach nuklearnych w 2006 roku, razem z innymi państwami wchodzącymi w skład umowy, nałożyły na Koreę Północną ograniczenia handlowe. Kolejne testy, w 2009 roku, przyniosły zacieśnienie granic i kolejne sankcje ${ }^{26}$. Relacje między krajami powoli pogarszały się, a punkt krytyczny nadszedł w drugiej dekadzie XXI wieku.

\section{Rząd Xi Jinpinga a pomoc KRLD}

Śmierć Kim Jong-ila i przejęcie władzy przez jego syna Kim Jong-una w 2012 roku nie zmieniły polityki KRLD w sprawie programu nuklearnego ${ }^{27}$. Nie spotkało się to z aprobatą strony chińskiej, od lat faworyzującej denuklearyzację Półwyspu Koreańskiego. Sytuacji nie poprawiały incydenty, takie jak przejęcie przez straż graniczą Korei Północnej trzech chińskich kutrów rybackich w maju 2012 roku $^{28}$, mające negatywny wpływ na stosunki między państwami oraz opinię publiczną.

Mimo początkowych dobrych chęci ze strony chińskiej, sytuacja pogorszyła się jeszcze bardziej po objęciu urzędu sekretarza generalnego Komunistycznej Partii Chin przez Xi Jinpinga w 2012 roku. Testy rakietowe, mające miejsce w tym samym roku, jak również groźby kolejnych prób jądrowych stawiały relacje Chin z KRLD pod znakiem zapytania. Sam Xi Jinping niejednokrotnie wyraził swój sprzeciw wobec dalszych testów północnokoreańskiej broni masowego rażenia, także w rozmowach z delegatami Korei Południowej ${ }^{29}$.

W lutym 2013 roku miała miejsce trzecia próba jądrowa, przeprowadzona pomimo protestów ze strony chińskiej, a razem z nią znaczne oziębienie stosunków Chin i Korei Północnej. Nałożone zostały kolejne sankcje, zaś chińskie banki pozamykały konta wysoko postawionych koreańskich urzędników

\footnotetext{
${ }^{25}$ Ibidem.

${ }^{26}$ International Crisis Group, Shades of Red: China's Debate over North Korea, „Asia Report” 2009, No. 179, https://www.crisisgroup.org/asia/northeastasia/koreanpeninsula/shadesredchinas debateovernorthkorea (dostęp: 20.04.2020).

${ }^{27}$ H. Kim, China's Policy Toward North Korea under the Xi Finping Leadership, „North Korean Review” 2013, No. 9(2), www.jstor.org/stable/43908922 (dostęp: 24.04.2020).

${ }^{28}$ Ibidem.

${ }^{29}$ Ibidem.
} 
państwowych i czasowo uniemożliwiły im operowanie zgromadzonymi środka$\mathrm{mi}^{30}$. Czasowo zablokowano również ruch turystyczny. Ograniczenia odbiły się na polityce wielu chińskich firm prowadzących działania w relacji z Koreą Północną, nadwyrężając ich zaufanie ${ }^{31}$. Relacje dyplomatyczne znacząco osłabły, ale obustronne powiązania ekonomiczne stawały się coraz silniejsze. Jednocześnie wzrastały kontakty Chin z Koreą Południową, ku niezadowoleniu rządu Kim Jong-una. Władze KRLD zaczęły otwarcie wyrażać sprzeciw ideologiczny wobec reform zachodzących $\mathrm{w} \mathrm{Chinach}^{32}$. Doprowadziło to do niezręcznej dla obu stron sytuacji - napięcia wzrastały z każdym kolejnym testem nuklearnym, niosącym kolejne sankcje międzynarodowe. Powiązania sprawiły, że Chiny utraciły możliwość wywierania presji na decyzje rządu północnokoreańskiego ${ }^{33}$. Jednak nawet jeśli stosunki dyplomatyczne państw nie były w najlepszym stanie, program pomocy zagranicznej wciąż działał ${ }^{34}$. Wbrew niejednokrotnym słowom krytyki pod adresem polityki KRLD, rządowi Xi Jinpinga nadal zależało na utrzymaniu reżimu Kim Jong-una przy władzy, by nie ryzykować zbytniej destabilizacji regionu.

Po niezwykle trudnym i intensywnym okresie kontrowersyjnych decyzji północnokoreańskich w latach 2016 i 2017 wymiana handlowa kraju z Chinami osiągnęła swój najniższy próg ${ }^{35}$ od czasu przejęcia władzy przez Kim Jong-una. W drugiej połowie 2018 roku nadeszły jednak pierwsze sygnały poprawy. Załagodzenie polityki zagranicznej KRLD przywróciło ich dialog z USA, Koreą Południową, jak również Chinami ${ }^{36}$. Doprowadziło to do pierwszych w historii spotkań Xi Jinpinga z Kim Jong-unem w Chinach, jak również wizyty Xi w Pyongyangu w 2019 roku $^{37}$. Rozmowy dały nadzieję na rozwiązanie pro-

${ }^{30}$ H.Y. Lee, North Korea in 2013: Economy, Executions, and Nuclear Brinksmanship, „Asian Survey" 2014, No. 54(1), s. 89-100; Bank of China Closes Account of Key North Korean Bank, CNBC, 2013, https://www.cnbc.com/id/100718118 (dostęp: 24.04.2020).

31 朝鲜第三次核试后的中朝经贸合作走势 (Trendy w chińsko-północnokoreańskiej współpracy handlowej i ekonomicznej po trzecim koreańskim teście nuklearnym), 丹东华商海外投 资有限公司 (Międzynarodowa Komercyjna Firma Inwestycyjna Dandong), 2013, http://www. cxtzw.com/Affiche.asp?ID=62 (dostęp: 15.12.2019).

${ }^{32}$ M. Hoshino, S. Hiraiwa, Four factors in the „special relationship” between China and North Korea: a framework for analyzing the China-North Korea Relationship under Xi Finping and Kim Fongun, „Journal of Contemporary East Asia Studies” 2020, No. 9, s. 1-11, https://doi.org/10.1080 /24761028.2020.1754998 (dostęp: 23.04.2020).

${ }^{33}$ Ibidem.

${ }^{34}$ Ibidem.

${ }^{35}$ J. Lee, North Korean Trade with Key Partner China Dives amid Sanctions, „South China Morning Post” 2019, https://www.scmp.com/news/china/diplomacy/article/3019348/northkoreantradebiggestpartnerchinadives48centamid (dostęp: 23.04.2020).

${ }^{36}$ M. Hoshino, S. Hiraiwa, op. cit.

${ }^{37}$ Tiezzi. S., Xi finping Is (Finally) Visiting North Korea, „The Diplomat”, 2019, https://thediplomat.com/2019/06/xijinpingisfinallyvisitingnorthkorea/ (dostęp: 24.04.2020). 
blemów i zmniejszenie ryzyka w kontaktach chińskich z KRLD ${ }^{38}$. Zapowiedziane pogłębienie współpracy już w pierwszej połowie 2019 roku dało namacalne skutki w zwiększeniu wymiany handlowej między państwami ${ }^{39}$. Chiny nie przestają być największym inwestorem i źródłem pomocy zagranicznej dla KRLD do dziś.

\section{Od ideologii do partnerstwa}

$\mathrm{Z}$ biegiem lat, także w sprawie pomocy zagranicznej, ChRL staje się coraz bardziej pragmatyczna. Szczególnie widać to w polityce prowadzonej przez rząd Xi Jinpinga od 2013 roku. W działaniach brak już sentymentu, walki o ideologię. Priorytetem w chińskich relacjach międzynarodowych nie jest rewolucja, radykalne zmiany, państw nie łączy już ideologia, a ich niegdyś specjalna więź coraz bardziej się normalizuje ${ }^{40}$. Chodzi przede wszystkim o to, by iść „drogą środka”, obopólnie korzystnej współpracy. Chiny to w wielu przypadkach jedyny obecny partner handlowy Korei Północnej ${ }^{41}$. Z tego właśnie powodu bardzo mało prawdopodobne jest, by nawet kolejne sankcje międzynarodowe obejmujące Koreę Północną nakłoniły Chiny do rezygnacji z własnego programu pomocy rządowi Kim Jong-una. Jak tłumaczą chińscy eksperci: „Pierwsze [sankcje - M.B.] to efekt odpowiedzialności międzynarodowej i moralna powinność; drugie [pomoc i relacje ekonomiczne - M.B.] pozwalają zachować stabilność, bezpieczeństwo w regionie i humanitaryzm" ${ }^{42}$.

\section{Bibliografia}

Bank of China Closes Account of Key North Korean Bank, CNBC 2013, https://www. cnbc.com/id/100718118 (dostęp: 24.04.2020).

唇齿相依（汉语成语）_百度百科 (Być blisko jak zęby i usta; analogia chińska), https:// baike.baidu.com/item/\%E5\%94\%87\%E9\%BD\%BF\%E7\%9B\%B8\%E4\%BE\%9D/2069313 (dostęp: 23.04.2020).

Chan C., Bridges B., Divergence and Diversity: Changing Chinese Perceptions of North Korea under Kim fong-un, ,Journal of Contemporary China” 2018, No. 109(27), s. 16-31, https://doi.org/10.1080/10670564.2017.1363013 (dostęp: 23.04.2020).

${ }^{38} \mathrm{~J}$. Lee, Xi Vows to Work with Pyongyang on „Political Resolution” to Nuclear Issue, „South China Morning Post”, 2019, https://www.scmp.com/news/china/diplomacy/article/3015472/xijinpingandkimjongunpresentunitedfrontagainst (dostęp: 23.04.2020).

${ }^{39}$ Idem, China-North Korea Trade up 14 per Cent in First Half to US\$1.25 Billion, „South China Morning Post”, 2019, https://www.scmp.com/news/china/diplomacy/article/3019940/chinasfirsthalftradenorthkorearecoversoldallies (dostęp: 23.04.2020).

${ }^{40} \mathrm{C}$. Chan, B. Bridges, Divergence and Diversity: Changing Chinese Perceptions of North Korea under Kim fongun, „Journal of Contemporary China” 2018, No. 109(27), s. 16-31, https://doi.org/ 10.1080/10670564.2017.1363013 (dostęp: 23.04.2020).

${ }^{41}$ H.Y. Lee, op. cit.

${ }^{42} \mathrm{~J}$. Reilly, op. cit. 
Chen S., China Prepared to End North Korea Student Exchanges, „South China Morning Post” 2017, https://www.scmp.com/news/china/article/2122309/china-warns-it-ready-end-north-korea-student-exchanges-after-latest (dostęp: 23.04.2020).

Choo J., Mirroring North Korea's Growing Economic Dependence on China: Political Ramifications, „Asian Survey” 2008, No. 2(48), s. 343-372, https://doi.org/10.1525/ as.2008.48.2.343 (dostęp: 23.04.2020).

Chung J.H., Choi M., Uncertain allies or uncomfortable neighbors? Making sense of China-North Korea Relations, 1949-2010, „The Pacific Review” 2013, No. 26/3, https:// www.tandfonline.com/doi/abs/10.1080/09512748.2012.759262 (dostęp: 23.04.2020).

Hoshino M., Hiraiwa S., Four factors in the „special relationship” between China and North Korea: a framework for analyzing the China-North Korea Relationship under Xi finping and Kim fong-un, „Journal of Contemporary East Asia Studies” 2020, nr 9, s. 1-11, https://doi.org/10.1080/24761028.2020.1754998 (dostęp: 23.04.2020).

International Crisis Group, Shades of Red: China's Debate over North Korea, „Asia Report” 2009, No. 179, https://www.crisisgroup.org/asia/north-east-asia/korean-peninsula/shades-red-china-s-debate-over-north-korea (dostęp: 20.04.2020).

Kim H., China's Policy Toward North Korea under the Xi Finping Leadership, „North Korean Review" 2013, No. 9(2), www.jstor.org/stable/43908922 (dostęp: 24.04.2020).

Kwon H., The Korean War and Sino-North Korean Friendship 朝鮮戦争と中朝友 好関係, „The Asia-Pacific Journal/Japan Focus” 2013, No. 11/32/4, https://apjjf. org/2013/11/32/Heonik-Kwon/3982/article.html,eilly (dostęp: 20.04.2020).

Lee H.Y., North Korea in 2013: Economy, Executions, and Nuclear Brinksmanship, „Asian Survey” 2014, No. 54(1), s. 89-100, https://doi.org/10.1525/as.2014.54.1.89 (dostęp: 13.01.2020).

Lee J., China-North Korea Trade up 14 per Cent in First Half to US\$1.25 Billion, „South China Morning Post” 2019, https://www.scmp.com/news/china/diplomacy/article/3019940/ chinas-first-half-trade-north-korea-recovers-old-allies (dostęp: 23.04.2020).

Lee J., North Korean Trade with Key Partner China Dives amid Sanctions, „South China Morning Post” 2019, https://www.scmp.com/news/china/diplomacy/article/3019348/ north-korean-trade-biggest-partner-china-dives-48-cent-amid (dostęp: 23.04.2020).

Lee J., Xi Vows to Work with Pyongyang on „Political Resolution” to Nuclear Issue, „South ChinaMorningPost" 2019, https://www.scmp.com/news/china/diplomacy/article/30 15472/xi-jinping-and-kim-jong-un-present-united-front-against (dostęp: 23.04.2020).

Lin J., Jin M., 金正恩执政后朝鲜经济好转原因及其走势 (Przyczyny i trendy poprawy ekonomicznej w Korei Północnej po przejęciu władzy przez Kim Jong Una), 国外马 克思主义政党研究网 (Sieć badawcza zagranicznej partii marksistowskiej) 2020, http://www.ccnumpfc.com/index.php/View/147.html (dostęp: 23.04.2020).

Mao Zedong's Remarks at the Banquet for the North Korean Government Delegation, Wilson Center Digital Archive 1953, https://digitalarchive.wilsoncenter.org/document/114167 (dostęp: 23.04.2020).

Reilly J. The Curious Case of China's Aid to North Korea, „Asian Survey” 2014, No. 6(54), s. 1158-1183, https://doi.org/10.1525/as.2014.54.6.1158 (dostęp: 13.01.2020).

Tiezzi S., Xi finping Is (Finally) Visiting North Korea, „The Diplomat” 2019, https://thediplomat.com/2019/06/xi-jinping-is-finally-visiting-north-korea/ (dostęp: 24.04.2020). 
中华人民共和国商务部对外援助司 (strona internetowa People's Republic of China Foreign Aid), http://yws.mofcom.gov.cn/article/b/ (dostęp: 23.04.2020).

朝鲜第三次核试后的中朝经贸合作走势 (Trendy w chińsko-północnokoreańskiej współpracy handlowej i ekonomicznej po trzecim koreańskim teście nuklearnym), 丹东区商海外投资有限公司 (Międzynarodowa Komercyjna Firma Inwestycyjna Dandong) 2013, http://www.cxtzw.com/Affiche.asp?ID=62 (dostęp: 15.12.2019).

中华人民共和国政府和朝鲜民主主义人民共和国政府关于共同建设、管理和维 护中朝图们一南阳口岸新界河公路桥的协定 (Umowa między rządem Chińskiej Republiki Ludowej i rządem Koreańskiej Republiki Ludowo-Demokratycznej wsprawiewspólnejbudowy,zarządzaniaiutrzymaniamostunarzeceTumen-Nanyang w Nowym Terytorium), 中华人民共和国外交部 (Ministerstwo Spraw Zagranicznych Chińskiej Republiki Ludowej) 2015, https:/www.fmprc.gov.cn/web/ziliao_674904/tytj_674911/tyfg_674913/t1453671.shtml (dostęp: 2.04.2020). 